\title{
Pengaruh Penanganan Pascapanen dan Pola Suply Chain Management (SCM) terhadap Pendapatan Petani Beras Hitam di Kabupaten Sukabumi
}

\section{The Effect of Postharvest Handling and Suply Chain Management (Scm) Pattern on Black Rice Farmers in Sukabumi Distric}

\author{
Neneng Kartika Rini 1) dan Venita Sofiani ${ }^{2)}$ \\ 1 Pertanian, Universitas Muhammadiyah Sukabumi nenengkartikarini@ummi.ac.id \\ 2 Ekonomi, Universitas Muhammadiyah Sukabumi_venitasofiani@ummi.ac.id
}

\begin{abstract}
ABSTRAK
Beras Hitam adalah komoditas lokal yang ternyata tidak ditemukan di daerah Ciemas Kabupaten Sukabumi saja, pada beberapa Kecamatan di Kabupaten Sukabumi, yaitu Kecamatan Waluran, Cidolog, dan Kabandungan. Beras hitam dari kandungan nutrisi dan manfaatnya tidak kalah hebat. Harga Beras Hitam lebih tinggi dari beras putih atau beras konsumsi. Setiap petani Black Rice masih memiliki masalah dalam melaksanakan proses penanganan pascapanen. Ini adalah kasus dengan manajemen Rantai Suply (SCM) atau manajemen rantai pasokan oleh petani, ini juga dilakukan oleh petani dengan pola yang berbeda. Pendapatan petani padi sawah menjadi tidak menentu. Karena keuntungan dari beras hitam dan pendapatan petani yang berfluktuasi di setiap tahun, perlu untuk memeriksa penanganan pascapanen dan untuk mengetahui dan menganalisa bagaimana alur kerja yang efisien untuk mempercepat manajemen rantai pasokan, beras hitam mencapai konsumen dan mendapatkan keuntungan yang lebih besar. daripada menghabiskan uang untuk pengusaha beras hitam. Hasil menunjukan proses penanganan pascapanen dan pola SCM mempengaruhi pendapatan petani di di Waluran, Ciemas, Surade, Cidolog, dan Kabandungan Kabupaten Sukabumi.
\end{abstract}

Kata kunci: Penanganan pascapanen, manajemen rantai pasok, Pendapatan Petani, beras hitam, Kabupaten Sukabumi

\section{ABSTRACT}

Black Rice is a local commodity which apparently was not found in the Ciemas area of Sukabumi Regency alone, in several Districts in Sukabumi Regency, namely in the Districts of Waluran, Cidolog, and Kabandungan. Black rice from the nutritional content and benefits is no less great. Black Rice prices are higher than white rice or consumption rice. Every Black Rice farmer still has problems in carrying out the postharvest handling process. This is the case with Chain Management (SCM) or supply chain management by farmers, this is also done by farmers with different patterns. The income of lowland rice farmers is uncertain. Because the benefits of black rice and farmers' income fluctuate every year, it is necessary to check postharvest handling and to know and analyze how efficient workflows are to accelerate supply chain management, black rice reaches consumers and makes greater profits. rather than spending money on black rice entrepreneurs. The results show that the postharvest handling process and the SCM pattern affect the income of farmers in Waluran, Ciemas, Surade, Cidolog, and Kabandungan, Sukabumi Regency.

Keywords: Postharvest handling, supply chain management, Farmer Income, black rice, Sukabumi Regency 


\section{PENDAHULUAN}

\subsection{Latar Belakang}

Pendapatan daerah (PAD), merupakan hal pokok yang diperlukan menuju kemandirian wilayah menyongsong otonomi daerah dan desentralisasi. Untuk itu daerah harus memaksimalkan sumbersumber pendapatan daerah dan berinovasi mencari sumber lain. Pendapatan masyarakat. Daerah yang mandiri dan maju akan diperlihatkan oleh kemakmuran masyarakatnya (social welfare) ditandai dengan pendapatan yang tinggi. Pendapatanpetani yang tinggi akan menciptakan sumber pembiayaan pembangunan dari saving, investasi dan produktivitas yang tinggi.

Beras menyediakan protein dari nutrisi berkualitas tinggi, dan juga mineral, vitamin dan serat. Ada 20 jenis beras yang dikenal, hanya Oryza sativa dan Oryza glaberrima yang dibudidayakan dan merupakan jenis beras yang biasa dikonsumsi. Dari beberapa produk beras Oryza sativa ada beberapa jenis yang tidak umum dari segi aroma, warna biji dan komposisi kimianya, berasberas itu disebut dengan "beras khusus". Terdapat beragam warna padi/beras dan warna tergantung pada pigmen warna khususnya antosianin pada lapisan pericarp, kulit biji (seed coat), tetapi sebagian besar beras yang dikonsumsi adalah beras putih. Dengan semakin meningkatnya kemakmuran, permintaan untuk beras khusus ini juga bertambah. Salah satu beras khusus yang banyak pertmintaannya adalah beras hitam yang bertambah pesat.

Perlu kiranya dilakukan penelitian yang berkaitan penanganan pasca panen, alur operasional rantai pasok, serta pengaruh dan hubungan keduanya terhadap pendapatan petani. Hal ini dilaksanakan guna meningkatkan, mengembangkan, serta menyiapkan produk secara kontinyu yang sesuai kebutuhan serta kualitas yang diharapkan konsumen, juga wisatawan yang berkunjung.

\section{II.METODE PENELITIAN}

\subsection{Lokasi danWaktu}

Peneletian ini dilaksanakan di Kawasan Kecamatan Kabandungan, Kabupaten Sukabumi, Provinsi Jawa Barat. Adapun waktu pelaksanaan kajian dimulai dari bulan Februari- Agustus 2018 .Beberapa lokasi spesifik yang menjadi pusat kajian adalah kecamatan dan desa yang berada di wilayah Kabupaten Sukabumi.

\subsection{Metode Desain Penelitian}

Kajian ini dilakukan dengan metode



Gambar 1. Desain Jaringan Mangiemen Rantai Pasokan Beras Hitam di Dess Ciananga Kabandungan

Sumber: Data Olahan Bulan, Juni 2018

deskriptif kualitatif melalui pendekatan survei dalam pengumpulan datanya.Kajian deskriptif lebih ditekankan pada penemuan fakta yang ada di lapangan daerah interpretasi yang tepat. Adapun survei merupakan suatu teknik pengumpulan data yang bertujuan untuk mengumpulkan data yang relatif besar 
jumlahnya dalam suatu populasi. Survei dilakukan dengan memberikan pertanyaan-pertanyaan kepada responden terpilih dengan menggunakan kuesioner sebagai instrumen pengumpulan data dari suatu populasi. Alat Uji analisi yang digunakan adalah Deskripsif kuantitatif , Alur operasional Suplai Chain, dan Chi square untuk melihat korelasi hubungan.

\section{HASIL DAN PEMBAHASAN}

Berdasarkan Gambar 1. diatas dapat dijelaskan bahwa alur rantai pasokan beras hitam mulai dari petani hingga konsumen pada 5 kecamatan adalah sebagai berikut : Harga beras hitan dari petani dalam gabah basah adalah 10.000 rupiah per kilogram, jika sudah dijemur dan digiling petani memberi harga 15.000 rupiah perkilogram. Sampai ke pengepul beras disortir dan dikemas dan dijual pada agen pengecer seharga 25.000 rupiah. Dari agen pengecer ke konsumen harga beras hitam 30.000 rupiah per kilogram.

Tabel.3.1 Tahapan Penganganan Pascapanen Beras Hitam di 5 Kecamatan Kabupaten Sukabumi

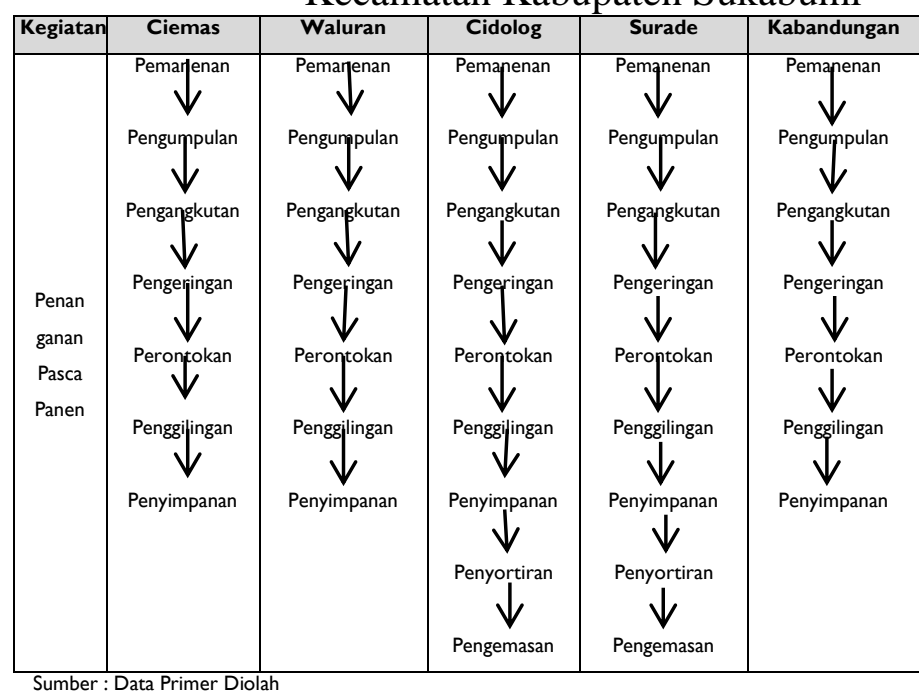

Berdasarkan Tabel 3.1 dari proses penanganan pasca panen dapat dijelaskan bahwa hanya 2 kecamatan yakni : Cidolog dan Surade yang melakukan proses Penyortiran. Sedangkan untuk 3 kecamatan yang lain tanpa penyortian, sehingga kualitas beras hitam pada 3 kecamatan tersebut masih belum bersih, warna merata, bentuk seragam sseperti pada hasil produk di kecamatan Cidolog dan Surade.

Sortasi merupakan bagian kegiatan pasca panen yang dilakukan dengan tujuan memisahkan hasil (pasca) panen yang baik dan yang jelek. Sortasi merupakan proses pengklasifikasian bahan berdasatkan sifat fisiknya. Sortasi juga dapat diartikan sebagai suatu kegiatan yang memisahkan produk berdasarkan tingkat keutuhan atau kerusakan produk, baik karena cacat karena mekanis ataupun cacat karena bekas serangan hama atau penyakit. Pada kegiatan sortasi, penentuan mutu hasil panen biasanya didasarkan pada kebersihan produk, ukuran, bobot, warna, bentuk, kematangan, kesegaran, ada atau tidak adanya serangan atau kerusakan oleh penyakit, adanya kerusakan oleh serangga, dan luka oleh faktor manusia, faktor fisik, atau mekanis. Sortasi selain dilakukan secara manual dapat pula dengan mesin. Prinsip sortasi menggunakan mesin mengacu pada sifat-sifat bulir beras (secara mekanis) sebagai dasar sortasi. Sifat-sifat beras itu meliputi: berat; ukuran (panjang, pendek, diameter); bentuk (bulat, lonjong, lurus, pipih dll.), karakteristik fotometrik (berdasarkan warna dan perubahan transmisi sorter); aerodinamik dan hidrodinamik: (pemisahan berdasarkan densitas atau daya apung secara alami; untuk keadaan ini digunakan pada alat sortasi, misal dengan cara menggetarkan dan mendorong). Apabila tidak dilakukan sortasi maka proses pengeringan dan 
pengolahan tidak merata. Misalnya bahan ukuran besar bercampur dengan ukuran kecil sehingga proses pengeringan dan pengolahan akan lebih cepat bahan berukuran kecil.

Beras mutu terbaik tersebut tentu tidak hadir dari proses yang asal. Beras terbaik tersebut mendapatkan perlakuan yang jauh lebih baik dari metode bertani kebanyakan, melalui dari penerapan teknologi sejak tahap penananaman, penanganan pascapanen, sampai prosesing pengarungan gabah dan pengarungan beras. Proses pengarungan dengan karung terbaik dilakukan sejak panen pada saat berupa gabah. Hal tersebut dilakukan sebagai upaya mutu gabah akan diikuti oleh peningkatan nilai tambah. Tanda gabah yang bermutu adalah menghasilkan beras dengan rendemen giling lebih tinggi dan mutu beras yang baik. Masyarakat kita pada umumnya sebagai konsumen beras dapat dikelompokkan menjadi tiga kelompok.

Pertama adalah kelompok bawah. Kelompok ini ingin mendapatkan beras dengan harga murah, bagaimanapun mutunya. Pertimbangan utama konsumen hanyalah kelayakan beras untuk dapat jelas dikonsumsi. Kelompok masyakat kelas bawah menginginkan ketersediaan beras dengan harga murah, sehingga kecukupan pangan hari-harinya terpenuhi. Kedua adalah kelompok sedang atau menengah. Mutu beras mendapat perhatian dengan kategori khusus seperti penampakan yang putih, persen butir kepala tinggi, rasa nasi pulen, dnamun dengan catatan harga yang masih terjangkau. Kelompok kelas menengah ini merupakan pasar paling besar dari konsumen beras. Untuk merebut pasar kelas menengah ini maka kondisi kemasan atau pengarungan beras yang baik menjadi penting sebagai atas merek atau branding kualitas mutu beras. Dan yang Ketiga adalah kelompok atas. Beras yang diharapkan dari kelas ekonomi atas adalah kualitas dengan mutu baik nyaris sempurna. Bahkan jika perlu mereka mencari mutu beras yang sempurna, tidak memperdulikan lagi berapa harga yang harus dibayarkan. Mereka menyukai kesempurnaan beras seperti kepala 100\%, penampakan yang putih bersih, mengkilat, utuh, rasa nasi pulen, dan memiliki aroma yang wangi.

Pengemasan atau karung beras yang tepat dapat mempertahankan mutu dan nilai gizi bahan pangan. Selain itu, karung beras dengan mutu terbaik juga mampu melindungi selama proses penyimpanan. Contoh penggunaan karung beras terbaik adalah plastik jenis HDPP (high density polypropilene). HDPP memiliki kekuatan penjagaan selama proses penyimpanan yang lebih baik dibandingkan dengan karung plastik atau plastik jenis PP (polypropilene).

Tabel.3.2 Tahapan Pola Suply Chain Management Beras Hitam di 5 Kecamatan Kabupaten Sukabumi

\begin{tabular}{|c|c|c|c|c|c|}
\hline Kegia & Ciemas & Waluran & Cidolog & Surade & Kabandungan \\
\hline $\begin{array}{c}\text { Suply } \\
\text { Chain } \\
\text { Manage } \\
\text { ment } \\
\text { (SCM) }\end{array}$ & $\downarrow_{\text {Tengkulak }}^{\text {Petani }}$ & $\downarrow_{\text {Tengkulak }}^{\text {Petani }}$ & $\downarrow$ & $\underset{\text { Agen }}{\stackrel{\text { Petani }}{\downarrow}}$ & $\downarrow_{\substack{\text { Petani } \\
\Downarrow \\
\text { Pengecer }}}^{\downarrow}$ \\
\hline
\end{tabular}

Berdasarkan Tabel 3.2 pada hasil dapat dijelaskan, bahwa Kecamatan Cidolog, Surade, dan Kabandungan yang sudah tidak melalui tengkulak atau pengepul dalam alur rantai pasokan 
petani beras hitam. Namun untuk kecamatan Waluran dan Ciemas masih melalui tengkulak dalam memasarkan produk beras hitamnya. Sehingga dapat dilihat pada Tabel 3.2 bahwa pendapatan petani di Kecamatan Waluran dan Ciemas lebih rendah dibandingkan pendapatan petani di Kecamatan Cidolog, Surade, dan Kabandungan.

Secara umum model rantai pasokan atau Suply Chain yang dilakukan pada 5 Kecamatan di Kabupaten Sukabumi adalah Vendor Managed Inventory (VMI), adalah merupakan salah satu variasi dari JIT II. Konsep ini banyak digunakan oleh para pemasok yang mensuplai bisnis retail. Selama ini pihak retail yang berkewajiban membuat order pembelian untuk menjaga kelangsungan persediaan dari setiap item yang terjual. Pada VMI kebalikannya, justru pemasoklah yang berkewajiban untuk menentukan kapan dan berapa jumlah suatu item harus dikirim ke retailnya, berdasarkan informasi tingkat penjualan dan ketersediaan stock yang ada diretail tersebut. Pada VMI pertukaran informasi yang lancar sangat diperlukan. Pemasok akan mampu membuat keputusan yang baik, apabila informasi tingkat kebutuhan maupun tingkat persediaan yang dimiliki pihak retail bisa diakses dengan mudah. Dari gambaran tersebut dapat dikatakan bahwa di 5 Kecamatan Kabupaten Sukabumi khususnya pada rantai pasokan Beras hitam sudah tidak menggunakanmodel JIT (Just In Time).

Tabel.3.3 Jumlah Rata-rata Produksi dan Pendapatan Rata-rata Petani Beras Hitam di 5 Kecamatan Kabupaten Sukabumi

\begin{tabular}{|l|c|c|c|c|c|}
\hline & Ciemas & Waluran & Cidolog & Surade & Kabandungan \\
\hline $\begin{array}{l}\text { Rata-rata } \\
\text { Produksi }\end{array}$ & 1,5 ton/ha & I ton/ha & 4,5 ton/ha & 5 ton/ha & 2,5 ton/ha \\
$\begin{array}{l}\text { Pendapat } \\
\text { an Rata- } \\
\text { rata }\end{array}$ & $\begin{array}{c}\text { Rp. } \\
\text { rata }\end{array}$ & $\begin{array}{c}\text { Rp. } \\
\text { Rp. }\end{array}$ & $\begin{array}{c}\text { Rp. } \\
1.600 .000\end{array}$ & $\begin{array}{c}\text { Rp. } \\
10.750 .000\end{array}$ & $\begin{array}{c}\text { Rp. } \\
13.500 .000\end{array}$ \\
& & & & 7.500 .000 \\
\hline
\end{tabular}

Berdasarkan Tabel 3.3 diatas dapat kitalihat hubungan jumlah rata-rata produksi beras hitam di 5 Kecamatan. Untuk Kecamatan Cidolog dan Surade, sistem budidaya beras hitam sudah mulai dibudidayakan di lahan kering persawahan, dan menggunakan sistem Organik, sehingga hasil produksi padi dapat mencapai 4,5 hingga 5 ton. Sehingga pendapatan petani cukup tinggi dibandingkan Kecamatan Kabandungan. Di kecamatan Ciemas dan waluran, budidaya beras hitam masih diusahakan petani di lahan-lahan pegunungan yang di multicropingkan dengan tanaman kayu. Peran sortasi dan pengemasan sangat besar terhadap peningkatan pendapatan petani, termasuk petani beras hitam. Meskipun ditambah biaya input untuk alat sortasi dan bahan pengemasan namun akan tertutupi oleh harga jual beras yang lebih tinggi. Rantai pasokan yang pendek dan tidak terlalu panjang akan meningkatkan pendapatan petani beras hitam. Pola alur rantai pasokan yang umum di lakukan di 5 Kecamatan di Kabupaten Sukabumi :

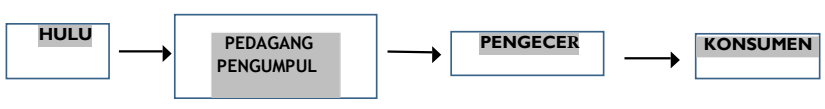

Dari hasil yang diperoleh, mulai dari penanganan pasca panen beras hitam, dan pola rantai pasokan yang dilakukan petani beras hitam sangat mempengaruhi hasil dan pendapatan petani beras hitam yang berbeda pada 5 kecamatan lokasi budidaya beras hitam spesifik kabupaten Sukabumi. Hal ini di perkuat dengan hasil Uji analisis hubungan dengan alat uji analisis Chi Square yang diperoleh Hasil Chi Square menunjukkan bahwa dengan rumus $\mathrm{x}$ aritmatika Chi $\left(\mathrm{x}^{2}\right)$ Square, maka diperoleh nilai $\mathrm{x}^{2}$ hitung 38,42 untuk Faktor Pendapatan dimana tabel $x^{2} h i t>x^{2}$, yang terbukti 34,42> 26,30, maka Ho 
ditolak, H1 diterima. Hasil uji hipotesis menunjukkan bahwa terdapat hubungan antara Penanganan Pasca Panen dan Pendapatan Petani Beras Hitam. Semakin Baik Proses penangan pasca Panen maka semakin besar pendapatan petani beras hitamdan terdapat hubungan antara Penanganan Pasca Panen dan Pola Suply Chain Management (SCM) Beras hitam terhadap peningkatan pendapatan petani.

\section{KESIMPULAN}

Dari hasil penelitian diperoleh beberapa hal sebagai berikut :

1. Penanganan Pasca Panen yang melalui tahapan penyortiran danpengemasan dapat meningkatkan kualitas beras hitam, sehingga dapat meningkatakan pendapatan petani beras hitam

2. Suply Chain Management (SCM) yang menggunakan pola sederhana atau rantai pasokan yang pendek, dapat meningkatkan pendapatan petani beras hitam.

3. Terdapat hubungan yang sangat signifikan antara penanganan pasca panen dan suply chain management (SCM) dengan besar nya pendapatan petani beras hitam.

\section{REFERENSI}

Andhen. 2010. Penanganan Pasca Panen Padi. P. T Penebar Swadaya

Anwar.S. 2012. Manajemen Rantai Pasokan.Konsep dan Hakikat.

BPS (Biro Pusat Statistik). 1996. Survei Susut Pascapanen MT. 1994/1995. Kerja sama Biro Pusat Statistik, Ditjen Pertanian Tanaman Pangan, Badan Pengendali Bimas, Badan Urusan Logistik, Badan
Perencanaan Pembangunan Nasional, Institut Pertanian Bogor, dan Badan Penelitian dan Pengembangan.

Kartika Rini, N. 2012. Pengaruh Preferensi Konsumen dan Konsistensi Standarisasi Anggrek Nasional Terhadap Daya Saing Anggrek Lokal dan Impor. Tesis. Prosiding Unsoed, ISBN:978-602- 70388-1-3 dan Nur Amalia, A.2014.Preferensi Konsumen Terhadap Produk Olahan Tepung Kulit Manggis. Prosiding Unsoed. ISBN:978- 602-70388-1-3 2015. Manajemen Agribisnis Beras Hitam Dalam Upaya Mengembangkan Komoditas Lokal di Kawasan Geopark Ciletuh Kabupaten Sukabumi. BukuKajian Geopark.ISBN:978-602-70388-1-3 dan Sofiani. V. 2017.

Pengaruh Preferensi Konsumen dan Faktor - Faktor yang Mempengaruhi Manajemen Pemasaran Beras Hitam di Geopark Ciletuh- Pelabuhan ratu. Jurnal Internasional. FOSSA

Mejio, D.J. 2008. An overview of ricepostharvest technology: Use of small metallic for minimizing losses. Agricultural Industries Officer, Agricultural and Food Engineering Technologies Service, FAO, Rome. FAO Corporate Document Repository. p.1-16.

Setyono A, Sutrisno, Nugraha S. 2001.Pengujian pemanenan padi sistem kelompok dengan memanfaatkan kelompok jasa pemanen dan jasa perontok. Penelitian Pertanian Tanaman Pangan. LIPI 